\title{
Variability in the production of tannins and other polyphenols in cell cultures of 12 Nordic plant species
}

\author{
Jussi Suvanto $^{1}$ (D) Liisa Nohynek ${ }^{2} \cdot$ Tuulikki Seppänen-Laakso $^{2} \cdot$ Heiko Rischer $^{2}$ • \\ Juha-Pekka Salminen ${ }^{1}$ Riitta Puupponen-Pimiä
}

Received: 16 December 2016/Accepted: 21 March 2017/Published online: 5 April 2017

(c) The Author(s) 2017. This article is an open access publication

\begin{abstract}
Main conclusion The polyphenol profiles of 18 cell cultures from 12 plant species were screened. The detected polyphenol fingerprints were diverse and differed from polyphenol profiles typically found in corresponding plant species.

Cell cultures originating from 12 different plant species growing or grown in the Nordic countries were screened for their ability to synthesize polyphenols to assess their suitability for future studies and applications. The focus was on plant families Rosaceae and Ericaceae. On average, the Rosaceae cultures were the most efficient to produce hydrolysable tannins and the Ericaceae cultures were the most efficient to produce proanthocyanidins. This is in line with the general trend of polyphenols found in Rosaceae and Ericaceae leaves and fruits, even though several individual cell cultures differed from natural plants in their polyphenolic composition. Overall, several of the studied cell cultures exhibited capability in producing a large variety of polyphenols, including tannins with a high molecular weight, thus also showing promise for further studies concerning, for example, the accumulation of specific polyphenols or biosynthesis of polyphenols in the cell cultures.
\end{abstract}

Jussi Suvanto

jussi.suvanto@utu.fi

1 Natural Chemistry Research Group, Department of Chemistry, University of Turku, 20014 Turku, Finland

2 VTT Technical Research Centre of Finland Ltd., 02044 Espoo, Finland
Keywords Anthocyanins · Flavonoids · Hydrolysable tannins · Plant cell suspension - Proanthocyanidins · UHPLC-DAD-MS ${ }^{2}$

$\begin{array}{ll}\text { Abbreviations } \\ \text { 3Q } & \text { Triple quadrupole } \\ \text { DAD } & \text { Photodiode array detector } \\ \text { ESI } & \text { Electrospray ionization } \\ \text { MS }^{2} & \text { Tandem mass spectrometry } \\ \text { U(H)PLC } & \begin{array}{l}\text { Ultra-high-performance liquid } \\ \text { chromatography }\end{array}\end{array}$

\section{Introduction}

Polyphenols are a diverse group of plant secondary metabolites found throughout the plant kingdom, encompassing such subgroups as tannins and flavonoids, among others. In plants, their biological function lies mostly within their defensive capabilities against herbivores, pathogens, and UV-B radiation (Haukioja 1991). In addition, numerous polyphenolic compounds have been found to be bioactive, for instance, due to their antioxidative, antimicrobial, antiviral, and antitumor activities (Okuda et al. 2009; Serrano et al. 2009). Tannins form structurally the most complex group of polyphenols, and they can be divided into hydrolysable tannins, proanthocyanidins (syn. condensed tannins), and phlorotannins. Plants rich in tannins have traditionally found use in leather tanning, hence their name, resulting from their ability to bind and precipitate proteins.

Publications reporting polyphenols from callus cultures date back to at least the 1960s (e.g., Constabel 1968; Davies 1972), and different polyphenolic compound groups identified include galloyl glucoses (e.g. 
Haddock et al. 1982), gallotannins (e.g., Krajci and Gross 1986), ellagitannins (e.g., Scalbert et al. 1988), proanthocyanidins (e.g., Oberthur et al. 1983), and anthocyanins (e.g., Nawa et al. 1993), and other flavonoids (e.g., Oberthur et al. 1983). The use of plant cell cultures, in general, could be beneficial in polyphenol studies, as they grow under very strictly and accurately controlled conditions allowing easy addition of hormones, biosynthetic precursors, and other compounds of interest. It has also been recently shown with Rubus chamaemorus that suspension cultures of plant cells can be scaled up to an industrial scale to create cell material having a defined chemical, including polyphenolic composition (Nohynek et al. 2014). This kind of mass-produced plant cell material can be used in various fields of industry, such as food and cosmetics, in place of natural plants to ensure consistent quality and to minimize the dependency on natural crops of plants that can vary both in quality and availability. Furthermore, for endangered species, biotechnical means of growing plant material in cell cultures may be the only way especially for industrial scale utilization in a sustainable way in the future, as has been suggested in some recent publications (Matkowski 2008; Nohynek et al. 2014).

Altogether, several of the aforementioned bioactivities are beneficial when tannins or other polyphenols, plants rich in them or cell cultures derived from polyphenol-rich plants are used in cosmetic (Barbulova et al. 2014; Zillich et al. 2015) and nutraceutical (Espín et al. 2007) products. In the cosmetic applications, the usage of polyphenols is often related to their purported anti-aging properties, caused mainly by their protection against lipid oxidation (Hagerman et al. 1998), ability to inhibit, e.g., tyrosinase activity on the skin (Parvez et al. 2007) and stabilize collagen (Madhan et al. 2005), and their photoprotective capabilities against UV radiation (Nichols and Katiyar 2010).

For this study, a total of 18 cell suspension cultures originating from 12 plant species, of which 10 were originally from Finland and one from Sweden and Norway each, were chosen for analyses on their polyphenolic profile by UHPLC-MS ${ }^{2}$ (ultra-high-performance liquid chromatography-tandem mass spectrometry). This screening was done to see which cultures would provide suitable platforms for future studies on producing polyphenols in a laboratory environment. The plant species represented eight different genera (Rubus, Fragaria, Sorbus, Vaccinium, Empetrum, Lonicera, Avena, and Hordeum) and four families (Rosaceae, Ericaceae, Caprifoliaceae, and Poaceae). For most of the species included, the previous cell culture studies concerning polyphenolic compounds are non-existent.

\section{Materials and methods}

\section{Chemicals}

ACS grade acetone was from VWR International S.A.S. (Fontenay-sous-Bois, France). LC-MS grade acetonitrile and formic acid was from Fluka Analytical (Sigma Aldrich Chemie GmbH, Steinheim, Germany). Water was purified with Millipore Synergy UV (Merck KGaA, Darmstadt, Germany) water purification system.

\section{Cell cultures}

Most of the used plant cell lines (Table 1) are included in VTT Technical Research Centre of Finland's proprietary culture collection (http://culturecollection.vtt.fi/) cryo-stored in liquid nitrogen or maintained as callus culture on solid medium by sub-culturing the cells regularly. The plant species included cloudberry ( $R$. chamaemorus L., sample codes Rc1 and Rc2), raspberry (Rubus idaeus L., sample code Ri), arctic bramble (Rubus arcticus L., sample codes Ra1 and Ra2), stone bramble (Rubus saxatilis L., sample codes Rs1 and Rs2), strawberry (Fragaria $\times$ ananassa (Duchesne ex Weston) Duschesne ex Rozier 'Senga Sengana', sample code Fa), mountain ash (Sorbus aucuparia L., sample codes Sa1 and Sa2), bilberry (Vaccinium myrtillus L., sample codes Vm1 and Vm2), lingonberry (Vaccinium vitis-idaea L., sample code Vv), black crowberry (Empetrum nigrum L., sample code En), blue honeysuckle (Lonicera caerulea L. var. kamtschatica, sample code Lc), oat (Avena sativa L., sample code As), and barley (Hordeum vulgare L., sample codes Hv1 and Hv2). R. saxatilis was originally from Nesland, Lofoten, Norway, and L. caerulea from Överkalix, Sweden. The rest were from Finland.

Suspension cultures of plant cell lines were initiated from soft callus, and cultivated in medium optimal for each cell line (Table 1) at $24 \pm 1{ }^{\circ} \mathrm{C}$ on an orbital shaker at 100-110 rpm. The plant cell lines As and Hv1 were cultivated in dark, the rest under a day-night illumination regime (photoperiod 16:8 $\mathrm{h}$, irradiation $40 \mu \mathrm{mol} \mathrm{m}^{-2} \mathrm{~s}^{-1}$ ). The cultures were sub-cultured regularly in fresh medium every $10 \pm 4$ days, depending on cell line, and step-wise up-scaled to $250 \mathrm{ml}$ flasks containing $60 \mathrm{ml}$ of culture. When sub-cultured, the biomass was diluted 1:3 and clumps of the callus were removed.

In general, the plant cells were cultivated in Erlenmeyer flasks from 70 to $700 \mathrm{ml}$ as culture volume at the conditions described above for each cell line. As exceptions, $R$. chamaemorus cells (Rc1 and Rc2) were obtained from two subsequent large scale cultivations in a fermenter of 3001 (Nohynek et al. 2014), and S. aucuparia cells (Sa1 and 
Table 1 Studied plant cell cultures, their VTT culture collection codes, colours of the culture, and used growth media

\begin{tabular}{|c|c|c|c|c|}
\hline Sample code & Plant cell culture & VTT culture collection code & Colour of the culture & Growth medium ${ }^{b}$ \\
\hline Rc1 & R. chamaemorus $\mathrm{L}$. & VTT P-120083 & Yellow & MS \\
\hline $\mathrm{Rc} 2$ & R. chamaemorus $\mathrm{L}$. & VTT P-120083 & Yellow & MS \\
\hline $\mathrm{Ri}$ & R. idaeus L. & VTT P-120090 & Green & MS \\
\hline Ra1 & R. arcticus $\mathrm{L}$. & VTT P-120089 & Red & MS-pH4 \\
\hline $\mathrm{Ra} 2$ & R. arcticus $\mathrm{L}$. & VTT P-120087 & Green & MS-pH4 \\
\hline Rs1 & R. saxatilis $\mathrm{L}$. & VTT P-120091 & Green & MS \\
\hline Rs2 & R. saxatilis $\mathrm{L}$. & VTT P-120091 & Yellow & MS \\
\hline $\mathrm{Fa}$ & $\begin{array}{l}\text { Fragaria } \times \text { ananassa }(\text { Duchesne ex Weston) } \\
\text { Duschesne ex Rozier 'Senga Sengana' }\end{array}$ & VTT P-120010 & Green & MS-pH4 \\
\hline Sa1 & S. aисираria $\mathrm{L}$. & VTT P-120084 & Green & MS \\
\hline $\mathrm{Sa} 2$ & S. aucuparia $\mathrm{L}$. & VTT P-120084 & Green & MS \\
\hline Vm1 & V. myrtillus L. & VTT P-120045 & Brownish & WP \\
\hline $\mathrm{Vm} 2$ & V. myrtillus L. & VTT P-120045 & Dark red & WP \\
\hline Vv & V. vitis-idaea $\mathrm{L}$. & KAS $377^{\mathrm{a}}$ & Yellow & WP \\
\hline En & E. nigrum $\mathrm{L}$. & KAS $446^{\mathrm{a}}$ & Dark red & WP \\
\hline Lc & L. caerulea L. var. kamtschatica & KAS $469^{a}$ & Yellow & MS \\
\hline As & A. sativa $\mathrm{L}$. 'Veli' & VTT P-120073 & Yellow & MS-mod \\
\hline Hv1 & H. vulgare L. 'Pokko' & VTT EC-P-120080 & Yellow & B5-mod \\
\hline Hv2 & H. vulgare L. 'Wolmari' & VTT P-120075 & Yellow & CIM \\
\hline
\end{tabular}

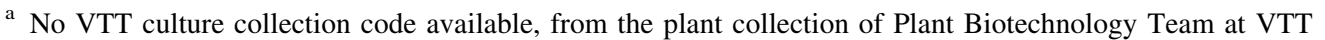

${ }^{\mathrm{b}}$ MS Murashige and Skoog medium (Murashige and Skoog 1962) (Duchefa Biochemie, The Netherlands) containing 3\% (w/v) sucrose, $0.1 \mathrm{mg} \mathrm{l}^{-1}$ kinetin (Sigma), and $1 \mathrm{mg}^{-1} \alpha$-naphthaleneacetic acid (Sigma). For solid medium, $8 \mathrm{~g} \mathrm{l}^{-1}$ Bacto agar (BD, Becton, Dickinson and Company, USA) was added; MS-pH $4=\mathrm{As}$ MS, but $\mathrm{pH}$ was decreased to 4.0 before autoclaving; WP woody plant medium (Duchefa Biochemie) containing 3\% (w/v) sucrose, $2.2 \mathrm{mg} \mathrm{l}^{-1}$ thidiazuron (Sigma P6186), and $1.95 \mathrm{mg}^{-1} \alpha$-naphthaleneacetic acid. For solid medium, $8 \mathrm{~g}^{-1}$ Bacto agar was added; $M S$-mod modified MS medium (Ritala et al. 2007) containing $2 \%$ (w/v) sucrose, $150 \mathrm{mg} 1^{-1}$ asparagine, and $2.0 \mathrm{mg} \mathrm{l}^{-1}$ 2,4-dichlorophenoxyacetic acid (Sigma). For solid medium, $3 \mathrm{~g} \mathrm{l}^{-1}$ Phytagel (Sigma) was added; B5-mod modified B5 medium

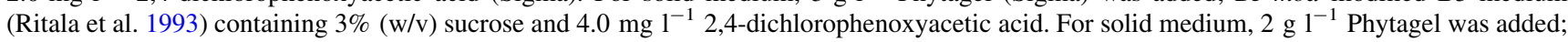
CIM medium as described by Ritala et al. (2008)

Sa2) were produced in BIOSTAT ${ }^{\circledR}$ CultiBag RM Wave bioreactor, consisting of a rocking unit (BioWave 20SPS; Wave Biotech AG, Tagelswangen, Switzerland) and a cultivation bag (CultiBag; Sartorius AG, Göttingen, Germany) of 21 . The plant cells were separated from the medium by vacuum filtration using a Büchner funnel and Miracloth tissue (Calbiochem, Merck KGaA), washed twice with sterile MilliQ water, and lyophilized. The lyophilized cell biomass was kept frozen $\left(-20^{\circ} \mathrm{C}\right)$ until extraction.

\section{Extraction}

$20 \mathrm{mg}$ of lyophilized and ground sample material was macerated overnight in $1400 \mu \mathrm{l}$ of acetone/water $(4: 1, \mathrm{v} / \mathrm{v})$ in a $2 \mathrm{ml}$ Eppendorf tube at $4{ }^{\circ} \mathrm{C}$, extracted on a planar shaker for $3 \mathrm{~h}$, and centrifuged, after which the supernatant was recovered. The extraction was repeated (omitting the maceration) and the supernatants were combined. Acetone was evaporated from the extracts in vacuo, and the extracts were finally frozen, lyophilized, and stored in $-20{ }^{\circ} \mathrm{C}$ until analyses. These extracts were used to determine all compounds except for anthocyanins. The total anthocyanin content was determined from methanol extracts of lyophilized and powdered samples showing at least traces of red, blue, or purple colour, as evaluated by eye. $10 \mathrm{mg}$ of the sample was mixed with $500 \mu$ of methanol in an Eppendorf tube, vortexed vigorously for $2 \mathrm{~min}$ and after 15 min of standing and occasional mixing centrifuged at $7800 \times \mathrm{g}$ for $5 \mathrm{~min}$. The supernatant was separated and stored in a glass $\mathrm{LC}$ vial at $-20{ }^{\circ} \mathrm{C}$ until analysis.

\section{UHPLC-DAD-3Q-MS ${ }^{2}$}

The first U(H)PLC system (Acquity UPLC ${ }^{\circledR}$, Waters Corporation, Milford, MA, USA) consisted of a binary solvent manager, a sample manager, a column (Acquity UPLC BEH Phenyl, $1.7 \mu \mathrm{m}, 2.1 \times 100 \mathrm{~mm}$, Waters Corporation), and a photodiode array detector (DAD). The photodiode array detector was set to operate between 190-500 $\mathrm{nm}$. The UHPLC system was connected to a Waters triple quadrupole mass spectrometer $\left(3 \mathrm{Q}-\mathrm{MS}^{2}\right.$; 
Xevo TQ, Waters Corporation) using electrospray ionization (ESI).

Lyophilized extracts were dissolved in $200 \mu \mathrm{l}$ of water and filtered using a syringe filter $(0.2 \mu \mathrm{m}$ PTFE, $13 \mathrm{~mm}$, VWR International GmbH, Darmstadt, Germany). Sample injection volume was $5 \mu \mathrm{l} .0 .1 \%$ formic acid (A) and acetonitrile (B) were used as eluents and the flow rate was kept at $0.5 \mathrm{ml} \mathrm{min}{ }^{-1}$ with the gradient as follows: $0.0-0.5 \mathrm{~min}, 0.1 \% \mathrm{~B}$ in $\mathrm{A}$; $0.5-5.0 \mathrm{~min}, 0.1-30.0 \% \mathrm{~B}$ in A (linear gradient); $5.0-8.0 \mathrm{~min}, 30.0-45.0 \% \mathrm{~B}$ in A (linear gradient); column wash and stabilization.

Negative full scan mode was used with ions being detected between $\mathrm{m} / \mathrm{z}$ (mass-to-charge ratio) 150-1200. Group-specific multiple reaction monitoring methods used for the detection of ellagitannins, gallic acid derivatives, quinic acid derivatives, kaempferol derivatives, quercetin derivatives, myricetin derivatives, and procyanidin and prodelphinidin terminal, and extensions units were as described by Engström et al. (2014, 2015). External calibration was used and the calibration curves were done by using purified tellimagrandin I $\left(0.47-7.50 \mu \mathrm{g} \mathrm{ml}^{-1}\right)$ for ellagitannins, pentagalloyl glucose $\left(0.06-1.00 \mu \mathrm{g} \mathrm{ml}^{-1}\right)$ for gallic acid derivatives, chlorogenic acid $\left(0.16-2.50 \mu \mathrm{g} \mathrm{ml}^{-1}\right)$ for quinic acid derivatives, kaempferol-3-O-glucoside $\left(0.13-2.00 \mu \mathrm{g} \mathrm{ml}^{-1}\right)$ for kaempferol derivatives, quercetin-3-O-galactoside $\quad(0.13-2.00 \mu \mathrm{g}$ $\mathrm{ml}^{-1}$ ) for quercetin derivatives, myricetin-3-O-rhamnoside $\left(0.56-9.00 \mu \mathrm{g} \mathrm{ml}^{-1}\right)$ for myricetin derivatives, and procyanidin (59-434 $\mu \mathrm{g} \mathrm{ml}^{-1}$ ) and prodelphinidin (159-1112 $\mu \mathrm{g} \mathrm{ml}^{-1}$ ) rich Sephadex LH-20 purified fractions for procyanidins and prodelphinidins. An ESI source was used with the temperature set at $150{ }^{\circ} \mathrm{C}$, desolvation temperature at $650{ }^{\circ} \mathrm{C}$, and capillary voltage at $3.4 \mathrm{kV}$. For full scan, a cone voltage ramp (30 V at $\mathrm{m} / \mathrm{z} 200$ to $50 \mathrm{~V}$ at $\mathrm{m} / \mathrm{z}$, 1000) was used. $\mathrm{N}_{2}$ was used as desolvation gas $\left(1000 \mathrm{l} \mathrm{h}^{-1}\right)$ and cone gas $\left(100 \mathrm{l} \mathrm{h}^{-1}\right)$. Argon was used as collision gas. The quantitation was done using the TargetLynx software (V 4.1, Waters Corporation).

\section{Anthocyanin analyses}

A second UHPLC system (Waters Acquity UPLC H-Class, Waters Corporation) equipped with an Acquity UPLC BEH C18 column $(1.7 \mu \mathrm{m}, 2.1 \times 100 \mathrm{~mm}$, Waters Corporation) was used for the analysis of anthocyanins. Used eluents were $0.1 \%$ formic acid (A) and acetonitrile (B), sample injection volume was $3 \mu \mathrm{l}$, solvent flow rate $0.3 \mathrm{ml} \mathrm{min}^{-1}$, and the gradient as follows: $0.0-1.1 \mathrm{~min}, 5-10 \% \mathrm{~B}$ in $\mathrm{A}$ (linear gradient); $1.1-5.7 \mathrm{~min}, 10-60 \% \mathrm{~B}$ in $\mathrm{A}$ (linear gradient); 5.7-9.0 min, 60-90\% $\mathrm{B}$ in $\mathrm{A}$ (linear gradient); 9.0-11.0 min, $90-100 \%$ B in A (linear gradient); column wash and stabilization. Quantification of anthocyanins was done by UV detection at $520 \mathrm{~nm}$. Cyanidin-3-glucoside was used as an external standard and the calibration curve was determined at a concentration range of $0.59-63.83 \mu \mathrm{g} \mathrm{ml}^{-1}$.

The identification on anthocyanins was confirmed on a Waters Q-Tof Premier mass spectrometer coupled to a Waters Acquity UPLC using the same column and gradient as for anthocyanin quantification. Electrospray ionization was used in positive mode and ions were detected between $\mathrm{m} / \mathrm{z}$ 100-1200. The conditions were set at as follows: capillary voltage $3.0 \mathrm{kV}$, sample cone voltage $45 \mathrm{~V}$, ion source temperature $120{ }^{\circ} \mathrm{C}$, desolvation gas $\left(\mathrm{N}_{2}\right)$ flow and temperature $8001 \mathrm{~h}^{-1}$ and $270{ }^{\circ} \mathrm{C}$, and collision gas (Ar) flow $0.601 \mathrm{~h}^{-1}$. Reserpine was used as a lock spray compound.

\section{UHPLC-DAD-Orbitrap-MS ${ }^{2}$}

A third UHPLC-MS system was used to achieve accurate mass spectral data on samples that showed the most promising polyphenolic fingerprints (samples Sa1, Vm1, and En). The UHPLC system, including the column, was identical to the one in the first system, but it was connected to a hybrid quadrupole-Orbitrap mass spectrometer ( $Q$ Exactive $^{\mathrm{TM}}$, Thermo Fisher Scientific $\mathrm{GmbH}$, Bremen, Germany).

The extracts made for UHPLC-DAD-3Q-MS ${ }^{2}$ analyses from these three samples were used as is for UHPLCDAD-Orbitrap-MS ${ }^{2}$ analyses. Sample injection volume was $5 \mu \mathrm{l} .0 .1 \%$ formic acid (A) and acetonitrile (B) were used as eluents and the flow rate was $0.5 \mathrm{ml} \mathrm{min}^{-1}$. The used gradient was as follows: $0.0-0.5 \mathrm{~min}, 0.1 \% \mathrm{~B}$ in A; 0.5-5.0 min, $0.1-30.0 \% \mathrm{~B}$ in $\mathrm{A}$ (linear gradient); 5.0-8.0 min, 30.0-45.0\% B in A (linear gradient); column wash and stabilization.

A heated ESI source (H-ESI II, Thermo Fisher Scientific $\mathrm{GmbH}$ ) was operated in negative ion mode and the following parameters were used: spray voltage, $-3.0 \mathrm{kV}$; sheath gas $\left(\mathrm{N}_{2}\right)$ flow rate, 60 (arbitrary units); aux gas $\left(\mathrm{N}_{2}\right)$ flow rate, 20 (arbitrary units); sweep gas flow rate, 0 (arbitrary units); capillary temperature, $380{ }^{\circ} \mathrm{C}$. A resolution of 70,000 was used in the Orbitrap detector, an automatic gain of $3 \times 10^{6}$ was used, and the mass range was set at $\mathrm{m} /$ $z$ 150-2000. For compound fragmentation studies, full MS/ dd-MS ${ }^{2}$ (TopN) experiments were performed using a loop count and TopN value of 5, a resolution of 17,500, and an automatic gain of $1 \times 10^{5}$. Pierce ESI Negative Ion Calibration Solution (Thermo Fischer Scientific Inc., Waltham, MA, USA) was used for the calibration of the detector. The data were processed with the Thermo Xcalibur Qual Browser software (Version 3.0.63, Thermo Fisher Scientific Inc.). 


\section{Results and discussion}

Gallic acid derivatives, ellagitannins, quinic acid derivatives, kaempferol derivatives, quercetin derivatives, myricetin derivatives, procyanidins, and prodelphinidins were quantified from all the 18 cell cultures using the UHPLCMS $^{2}$ methods described earlier by Engström et al. $(2014,2015)$. The concentrations of each of the quantified polyphenol groups are presented in Table 2. All plant cell cultures except for $R$. idaeus contained at least trace amounts of procyanidins and gallic acid derivatives, the latter of which consisted mainly of monogalloyl glucose isomers in all samples. Suspension cultures from three species, S. aucuparia, V. myrtillus, and E. nigrum, proved exceptionally interesting in their polyphenol content both qualitatively and quantitatively. One culture from all three of these species was chosen for more accurate qualitative analyses by Orbitrap mass spectrometry.

\section{Family Rosaceae}

A total of 10 cell suspension cultures were included from the family Rosaceae, representing three genera (Rubus, Fragaria, and Sorbus). From the genus Rubus, a total of seven cultures from four species ( $R$. chamaemorus L., $R$. idaeus $\mathrm{L}$., $R$. arcticus $\mathrm{L}$., and $R$. saxatilis $\mathrm{L}$.) were included. Rubus plants are most often characterized by high ellagitannin concentration in both their berries (Kähkönen et al. 2001; Nohynek et al. 2006) and leaves (Okuda et al. 1992), with the main ellagitannins typically being the dimeric sanguiin H-6 and the trimeric lambertianin C. Other phenolic compounds in $R$. idaeus include anthocyanins in fruits and flavonols, flavan-3-ols, proanthocyanidins, ellagic acid conjugates, and phenolic acids in both fruits and leaves (Harborne and Hall 1964; Ryan and Coffin 1971; Henning 1981; Törrönen et al. 1997; Kähkönen et al. 2001; Määttä-Riihinen et al. 2004b). Both fruits and leaves of the other three Rubus species included in the study are known to include very similar compounds to R. idaeus (e.g., Okuda et al. 1992; Törrönen et al. 1997; Häkkinen et al. 1999; Kähkönen et al. 2001; Määttä-Riihinen et al. 2004b).

In contrast, from the cultures included in this study, only the ones originating from $R$. saxatilis contained detectable levels of ellagitannins. In addition, the ellagitannins observed were determined to be monomers, and no traces of the characteristic oligomeric ellagitannins were detected. Besides ellagitannins, gallic acid derivatives were detected in all Rubus cultures except $R$. idaeus. Small amounts of proanthocyanidins were detected in five out of seven of the Rubus cultures, and flavonoids only in $R$. arcticus cultures. Anthocyanins were detected in Ra1 as cyanidin, delphinidin, petunidin, and peonidin glucosides, galactosides, and/or arabinosides.

Table 2 Concentrations of the different polyphenolic compound groups in each of the suspension culture samples

\begin{tabular}{|c|c|c|c|c|c|c|c|c|c|}
\hline \multirow{2}{*}{$\begin{array}{l}\text { Sample } \\
\text { code }\end{array}$} & \multicolumn{9}{|c|}{ Concentration ( $\mathrm{mg} \mathrm{g}^{-1}$ dry weight) } \\
\hline & $\begin{array}{l}\text { Gallic acid } \\
\text { derivatives }\end{array}$ & Ellagitannins & $\begin{array}{l}\text { Quinic acid } \\
\text { derivatives }\end{array}$ & $\begin{array}{l}\text { Kaempferol } \\
\text { derivatives }\end{array}$ & $\begin{array}{l}\text { Quercetin } \\
\text { derivatives }\end{array}$ & $\begin{array}{l}\text { Myricetin } \\
\text { derivatives }\end{array}$ & Procyanidins & Prodelphinidins & Anthocyanins \\
\hline Rc1 & $\operatorname{tr}$ & - & - & - & - & - & - & - & na \\
\hline Rc2 & 0.07 & - & - & - & - & - & 0.27 & - & na \\
\hline $\mathrm{Ri}$ & - & - & - & - & - & - & - & - & na \\
\hline Ra1 & $\operatorname{tr}$ & - & - & 0.23 & 0.44 & $\operatorname{tr}$ & 0.18 & - & 4.0 \\
\hline $\mathrm{Ra} 2$ & $\operatorname{tr}$ & - & - & - & - & $\operatorname{tr}$ & $\operatorname{tr}$ & - & na \\
\hline Rs1 & 0.11 & $\operatorname{tr}$ & - & - & - & - & $\operatorname{tr}$ & - & na \\
\hline Rs2 & 0.15 & $\operatorname{tr}$ & - & - & - & - & $\operatorname{tr}$ & - & - \\
\hline $\mathrm{Fa}$ & $\operatorname{tr}$ & - & - & - & - & - & 0.07 & - & na \\
\hline Sa1 & 0.33 & $\operatorname{tr}$ & - & - & - & - & $\operatorname{tr}$ & - & na \\
\hline $\mathrm{Sa} 2$ & 1.02 & 0.60 & - & - & - & - & $\operatorname{tr}$ & - & - \\
\hline Vm1 & $\operatorname{tr}$ & - & - & 0.06 & 0.18 & - & 20.88 & 0.17 & 2.8 \\
\hline $\mathrm{Vm} 2$ & $\operatorname{tr}$ & - & - & 0.08 & 0.21 & - & 26.26 & 0.18 & 4.8 \\
\hline Vv & $\operatorname{tr}$ & - & - & - & 0.08 & - & 0.22 & - & - \\
\hline En & $\operatorname{tr}$ & - & - & 0.08 & $\operatorname{tr}$ & - & 3.04 & 2.03 & 3.8 \\
\hline Lc & $\operatorname{tr}$ & - & 0.60 & - & - & - & $\operatorname{tr}$ & - & na \\
\hline As & $\operatorname{tr}$ & - & - & - & - & - & $\operatorname{tr}$ & - & na \\
\hline Hv1 & $\operatorname{tr}$ & - & - & - & - & - & $\operatorname{tr}$ & - & na \\
\hline Hv2 & $\operatorname{tr}$ & - & $\operatorname{tr}$ & - & - & - & $\operatorname{tr}$ & - & - \\
\hline
\end{tabular}

tr trace amounts, $n a$ not analyzed 
Fragaria $\times$ ananassa (Duchesne ex Weston) Duschesne ex Rozier 'Senga Sengana' was represented by one culture, and it proved to be fairly similar to several of the Rubus cultures in that it mainly consisted of small amounts of procyanidins and trace quantities of gallic acid derivatives. Earlier, López Arnaldos et al. (2001) have studied the changes in total soluble phenolics and flavanols, $(+)$-catechin, and ferulic acid and its glucoside in $F$. $\times$ ananassa callus cultures during their growth. They found that the concentrations of phenolic compounds peaked in the beginning of the exponential growth phase. As can be noted, the compounds they detected were not in line with the compound groups we identified to be present in our $F$. $\times$ ananassa suspension culture, which is most likely explained by different culture conditions, age, heritage of the culture, and different cultivar.

The phenolic content of the fruits of $F . \times$ ananassa has been studied fairly thoroughly, and they are known to contain ellagitannins and ellagic acid derivatives, proanthocyanidins, anthocyanins and other flavonoids including flavonols and flavan-3-ols, and hydroxycinnamic acids (Gil et al. 1997; Häkkinen et al. 1999; Aaby et al. 2007; Buendía et al. 2010).

The leaves of $F . \times$ ananassa, on the other hand, are not nearly as studied as the fruits, but they are known to contain ellagitannins, ellagic acid derivatives, galloyl glucoses, proanthocyanidins, flavonoids, and hydroxycinnamic acids (Skupień and Oszmiański 2004; Kårlund et al. 2014).

Two $S$. aucuparia L. suspension cultures cultivated by different methods were included. The culture Sa1 was cultivated in shake flasks, whereas the culture $\mathrm{Sa} 2$ was grown in a plastic cultivation bag in a wave type bioreactor. Their phenolic profiles were similar, consisting mostly of galloyl glucoses, ellagitannins, and procyanidins. Quantitatively culture $\mathrm{Sa}$, which was grown in a wave type bioreactor, had higher concentrations of both gallic acid derivatives and ellagitannins, showing its higher potential to produce these successive compound groups of the hydrolysable tannin pathway. The culture grown in shake flasks, Sa1, produced ellagitannins in trace quantities only, as did both $S$. aucuparia cultures procyanidins. The UV chromatogram $(\lambda=280 \mathrm{~nm})$ of the $S$. aucuparia culture $\mathrm{Sa} 2$ is presented in Fig. 1 and a more detailed characterization of the compounds detected in it is presented in Table 3. The main ellagitannins were identified as two isomeric galloyl-bis-HHDP- $\beta$-D-glucopyranoses and one trigalloyl-HHDP- $\beta$-D-glucopyranose. Galloyl glucoses from monogalloyl glucose to di-, tri-, tetra-, and pentagalloyl glucoses were detected as well (Fig. 2), with monoto trigalloyl glucoses appearing as several isomers.

The identities of these hydrolysable tannins were further confirmed by $\mathrm{MS}^{2}$ experiments. Galloyl glucoses showed characteristic fragments at $\mathrm{m} / \mathrm{z}$ values 169 and 125 ,

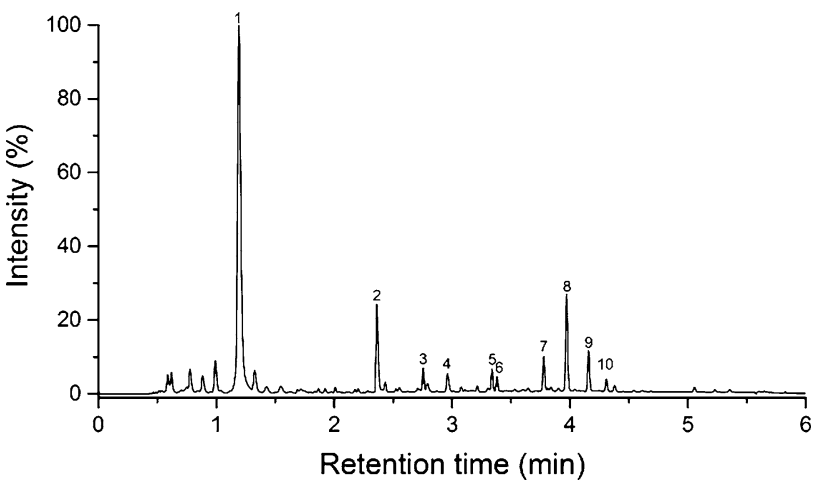

Fig. 1 UHPLC-DAD chromatogram $(\lambda=280 \mathrm{~nm})$ of the $S$. aucuparia suspension culture sample Sa2. For peak identification, see Table 3

corresponding to gallic acid and a subsequent cleavage of its $\mathrm{CO}_{2}$ unit (Lee et al. 2005). Fragments resulting from the cleavage of a galloyl or a gallic acid unit were detected, resulting in a loss of 152 or $170 \mathrm{Da}$ from the precursor ion, respectively. Ellagitannins were similarly detected by the presence of ions at $\mathrm{m} / \mathrm{z}$ values 301,275 , and 249 corresponding to ellagic acid, and a further loss of either one or two $\mathrm{CO}_{2}$ units, and a corresponding loss of $302 \mathrm{Da}$ from the precursor ion. The fragments presented for galloyl glucoses are often observed with ellagitannins, as they can also include galloyl groups. The identity of peak 2 could not be solved, but the accurate mass measurements suggest that it might contain two nitrogen atoms, making it not a true polyphenol, and that the two detected ions are $[\mathrm{M}-\mathrm{H}]^{-}$and $[2 \mathrm{M}-\mathrm{H}]^{-}$. Peaks 4 and 6 are very likely related to each other, as they have similar fragmentation patterns, and they might be hexosides, as the ion at $\mathrm{m} / \mathrm{z}$ 223 , resulting from a $162 \mathrm{Da}$ loss from the likely $[\mathrm{M}-\mathrm{H}]^{-}$ ion at $\mathrm{m} / \mathrm{z}, 385$, was of high intensity.

The compounds identified are in clear contrast to $S$. $a u$ cuparia berries, the phenolic profile of which has been reported to consist of hydroxycinnamic acids, hydroxybenzoic acids, anthocyanins, procyanidins, flavonols, and flavanols (Kähkönen et al. 2001), with 3-caffeoylquinic acid being the main compound contributing to $46 \%$ of $18.83 \mathrm{mg} \mathrm{g}^{-1}$ DW of total phenolics (Kylli et al. 2010). The leaves and inflorescences of $S$. aucuparia have not been studied as widely as the berries, but they contain phenolic acids, proanthocyanidins, and flavonoids (Olszewska and Michel 2009).

The profiles of the studied Rosaceae species cultures shared some similarities. Their average gallic acid derivative concentrations were higher than in the cultures of other plant families, and ellagitannins were only detected in Rosaceae cultures, albeit only in two of the six included species. This is in line with the fact that plants in the family Rosaceae are generally rich sources of hydrolysable 
Table 3 Compound identification for the Sorbus aucuparia culture sample Sa2

\begin{tabular}{|c|c|c|c|c|c|c|c|}
\hline Peak & $\begin{array}{l}\text { Tentative } \\
\text { compound } \\
\text { identification }\end{array}$ & $\begin{array}{l}\text { Molecular } \\
\text { formula }\end{array}$ & $\operatorname{MS}^{1}(m / z)$ & $\begin{array}{l}\mathrm{MS}^{2}, \text { characteristic } \\
\text { fragments }(m / z)^{\mathrm{a}}\end{array}$ & $\begin{array}{l}\text { Exact mass, } \\
\text { observed } \\
\left(\mathrm{g} \mathrm{mol}^{-1}\right)\end{array}$ & $\begin{array}{l}\text { Exact mass, } \\
\text { calculated } \\
\left(\mathrm{g} \mathrm{mol}^{-1}\right)\end{array}$ & $\begin{array}{l}\text { Error } \\
(\mathrm{ppm})\end{array}$ \\
\hline 1 & $\begin{array}{l}\text { 1-O-Monogalloyl- } \\
\beta \text {-D-glucose }\end{array}$ & $\mathrm{C}_{13} \mathrm{H}_{16} \mathrm{O}_{10}$ & $\begin{array}{l}331.0670 \\
{[\mathrm{M}-\mathrm{H}]^{-}}\end{array}$ & (331) $169.0130,125.0227$ & 332.0737 & 332.0743 & -1.8 \\
\hline 2 & Unknown & & $\begin{array}{l}407.1722 \\
203.0818\end{array}$ & $\begin{array}{l}\text { (203) } 159.0914,142.0647, \\
116.0489,72.0072\end{array}$ & & & \\
\hline 3 & Digalloyl glucose & $\mathrm{C}_{20} \mathrm{H}_{20} \mathrm{O}_{14}$ & $\begin{array}{l}483.0783 \\
{[\mathrm{M}-\mathrm{H}]^{-}}\end{array}$ & (483) $313.0565,169.0129$ & 484.0850 & 484.0853 & -0.6 \\
\hline 4 & Unknown & & 431.1193 & $\begin{array}{c}\text { (431) } 223.0606,208.0369, \\
179.0703,164.0466\end{array}$ & & & \\
\hline & & & 385.1141 & $\begin{array}{l}\text { (385) } 223.0604,208.0368 \\
179.0701,164.0465\end{array}$ & & & \\
\hline 5 & Trigalloyl glucose & $\mathrm{C}_{27} \mathrm{H}_{24} \mathrm{O}_{18}$ & $\begin{array}{l}635.0895 \\
{[\mathrm{M}-\mathrm{H}]^{-}}\end{array}$ & (635) 483.0778, 465.0672, 169.0129 & 636.0962 & 636.0963 & -0.2 \\
\hline 6 & Unknown & & $\begin{array}{l}771.2357 \\
385.1141\end{array}$ & $\begin{array}{l}\text { (771) } 223.0604,208.0367, \\
179.0701,164.0464\end{array}$ & & & \\
\hline 7 & $\begin{array}{l}\text { Galloyl-bis-HHDP- } \\
\beta \text {-D- } \\
\text { glucopyranose }\end{array}$ & $\mathrm{C}_{41} \mathrm{H}_{28} \mathrm{O}_{26}$ & $\begin{array}{c}935.0805 \\
{[\mathrm{M}-\mathrm{H}]^{-}} \\
467.0362 \\
{[\mathrm{M}-2 \mathrm{H}]^{2-}}\end{array}$ & (467) $300.9986,275.0193,169.0128$ & 936.0872 & 936.0869 & 0.4 \\
\hline 8 & $\begin{array}{l}\text { Trigalloyl-HHDP- } \\
\beta \text {-D- } \\
\text { glucopyranose }\end{array}$ & $\mathrm{C}_{41} \mathrm{H}_{30} \mathrm{O}_{26}$ & $\begin{array}{c}937.0956 \\
{[\mathrm{M}-\mathrm{H}]^{-}} \\
468.0438 \\
{[\mathrm{M}-2 \mathrm{H}]^{2-}}\end{array}$ & $\begin{array}{l}\text { (468) } 300.9987,275.0196 \\
249.0402,169.0128,125.0227\end{array}$ & 938.1023 & 938.1025 & -0.2 \\
\hline 9 & $\begin{array}{l}\text { Galloyl-bis-HHDP- } \\
\beta \text {-D- } \\
\text { glucopyranose }\end{array}$ & $\mathrm{C}_{41} \mathrm{H}_{28} \mathrm{O}_{26}$ & $\begin{array}{c}935.0797 \\
{[\mathrm{M}-\mathrm{H}]^{-}} \\
467.0361 \\
{[\mathrm{M}-2 \mathrm{H}]^{2-}}\end{array}$ & $\begin{array}{l}\text { (467) } 633.0732,300.9986 \\
275.0195,249.0400,169.0129\end{array}$ & 936.0864 & 936.0869 & -0.6 \\
\hline 10 & $\begin{array}{l}\text { Pentagalloyl } \\
\text { glucose }\end{array}$ & $\mathrm{C}_{41} \mathrm{H}_{30} \mathrm{O}_{26}$ & $\begin{array}{c}939.1123 \\
{[\mathrm{M}-\mathrm{H}]^{-}} \\
469.0521 \\
{[\mathrm{M}-2 \mathrm{H}]^{2-}}\end{array}$ & $\begin{array}{l}\text { (939) } 769.0902,617.0784 \\
\text { 465.0670, 447.0567, 169.0129, } \\
125.0228\end{array}$ & 940.1188 & 940.1182 & 0.7 \\
\hline
\end{tabular}

Peak numbers correspond to those presented in Fig. 1

${ }^{\text {a }}$ The ions marked in parentheses were used for $\mathrm{MS}^{2}$ fragmentation experiments

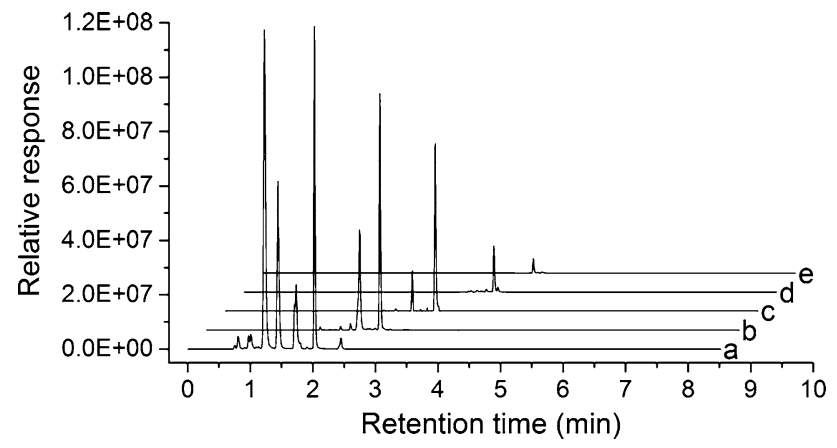

Fig. 2 Extracted ion chromatograms from $S$. aucuparia corresponding to the $\mathrm{m} / \mathrm{z}$ values of mono- $(a)$, di- $(b)$, tri- $(c)$, tetra- $(d)$, and pentagalloyl $(e)$ glucoses

tannins (Moilanen et al. 2015), and the possibility of using oligomeric ellagitannins as chemotaxonomic markers in Rosaceae has been suggested by Okuda et al. (1992), for example. All of the galloyl glucose producing Rosaceae cell cultures contained 1-O-monogalloyl- $\beta$-D-glucose, which is biosynthetically the first hydrolysable tannin, a precursor of all other hydrolysable tannins, and, therefore, an important intermediate in the hydrolysable tannin pathway. It remains unknown why it was not efficiently converted to biosynthetically following hydrolysable tannins.

\section{Family Ericaceae}

A total of four cell suspension cultures were included from the family Ericaceae, encompassing two genera (Vaccinium and Empetrum) and three species. V. myrtillus L. proved to be the most efficient producer of procyanidins among all studied suspension cultures by far; two $V$. myrtillus cultures were studied, and they contained 
$20.88 \mathrm{mg} \mathrm{g}^{-1} \mathrm{DW}$ and $26.26 \mathrm{mg} \mathrm{g}^{-1} \mathrm{DW}$ of procyanidins, contributing to $98 \%$ of total polyphenols. Several A-type proanthocyanidins were detected, which is in line with what has been found in $V$. myrtillus in nature (Hokkanen et al. 2009). As for other proanthocyanidins, prodelphinidins were found in much smaller quantities with $0.17 \mathrm{mg} \mathrm{g}^{-1}$ DW and $0.18 \mathrm{mg} \mathrm{g}^{-1}$ DW. Other compounds found in the $V$. myrtillus cultures were quercetin and kaempferol derivatives and gallic acid derivatives. The UV chromatogram $(\lambda=280 \mathrm{~nm})$ of the $V$. myrtillus culture $\mathrm{Vm} 2$ is presented in Fig. 3 alongside with a more detailed characterization of the compounds in Table 4.

The characteristic ions for the detected proanthocyanidins result from several types of cleavages; the ion at $\mathrm{m} / \mathrm{z}$ 407 results from retro-Diels-Alder fragmentation and subsequent elimination of water (Friedrich et al. 2000), ions at $\mathrm{m} / \mathrm{z}, 289$ and 287 result from quinone methide cleavage (Friedrich et al. 2000; Karonen et al. 2011), ion at $\mathrm{m} / \mathrm{z} 245$ likely from the loss of $-\mathrm{CH}_{2}-\mathrm{CHOH}$ group from a catechin unit (Pérez-Magariño et al. 1999), and ion at $\mathrm{m} / \mathrm{z}$ 125 corresponds to phloroglucinol resulting from heterocyclic ring fission (Gu et al. 2003). The identities of peaks 4 and 1 are tentatively identified as coumaroyl hexose and a coumaroyl hexose derivative, respectively, due to their mass fragmentation patterns showing signals at $\mathrm{m} / \mathrm{z}$ values 163 and 119 possibly resulting from coumaric acid and further cleavage of $\mathrm{CO}_{2}$ (Ma et al. 2007). Peak 12 was identified as a quercetin hexoside based on its UV spectrum and a product ion at $\mathrm{m} / \mathrm{z}, 300$, resulting from the homolytic cleavage of the $O$-glycosidic bond of the hexose (Hvattum and Ekeberg 2003). In addition, a product ion at $\mathrm{m} / \mathrm{z} 301$ corresponding to the quercetin aglycone was detected in the UHPLC-DAD-3Q-MS ${ }^{2}$ analyses, confirming its identity.

Beside the sharp peaks listed in Table 4, a chromatographic hump is visible in the chromatogram in Fig. 3 between approximately 3 and $6 \mathrm{~min}$. This corresponds to a

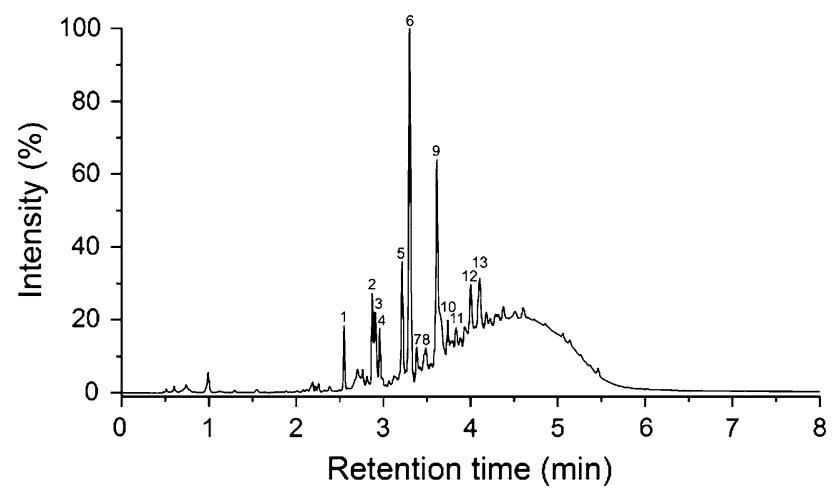

Fig. 3 UHPLC-DAD chromatogram $(\lambda=280 \mathrm{~nm})$ of the $V$. myrtillus suspension culture sample Vm2. For peak identification, see Table 4 mixture of a multitude of different isomers of proanthocyanidin oligo- and polymers, which are not resolved when using reversed-phase liquid chromatography, except for some small oligomers. The mean degree of polymerization for the proanthocyanidins in this hump, however, can be determined using $\mathrm{MS}^{2}$ methods for both procyanidins and prodelphinidins (Engström et al. 2014). For both of the two $V$. myrtillus culture samples, these mean degrees of polymerization were calculated to be 5 .

The berries of $V$. myrtillus have long been known to be rich in anthocyanins (Suomalainen and Keränen 1961). They include five different anthocyanidin aglycones (cyanidin, delphinidin, peonidin, petunidin, and malvidin), all appearing with three glycones (arabinose, glucose, and galactose), giving it a characteristic fingerprint profile of 15 different anthocyanins, which has for example been suggested for use in $V$. myrtillus product authenticity studies (Primetta et al. 2013). The two studied V. myrtillus cell cultures differed from this profile slightly, as no malvidin aglycones were detected. All of the other four aglycones and their corresponding three types of glycosides were detected.

Besides anthocyanins, the phenolic compounds of $V$. myrtillus berries include other flavonoids, proanthocyanidins, hydroxycinnamic acids, and ellagic acid (Wildanger and Herrmann 1973; Törrönen et al. 1997; Häkkinen et al. 1999;).

The phenolic compounds of the leaves, similarly to berries, of $V$. myrtillus include anthocyanins, proanthocyanidins, flavonoids, hydroxycinnamic acids, coumaroyl iridoids, and cinchonains (Riihinen et al. 2008; Hokkanen et al. 2009). The leaf anthocyanins are present only in the red leaves of $V$. myrtillus, which result from exposure to sunlight and subsequent accumulation of anthocyanins to protect from UV-B radiation (Chalker-Scott 1999; Jaakola et al. 2004).

The polyphenol profile of the V. vitis-idaea L. culture was somewhat similar to that of the $V$. myrtillus culture, containing mostly procyanidins and quercetins, though especially procyanidins in much lower concentrations. The phenolic profile of the leaves of $V$. vitis-idaea has been determined to mostly consist of flavonoids, including catechin and epicatechin, and simple phenolic acids, with some proanthocyanidins, cinchonains, and coumaroyl iridoids (Ek et al. 2006; Hokkanen et al. 2009). The berries contain all of these, with the addition of anthocyanins (Andersen 1985; Häkkinen and Auriola 1998; Määttä-Riihinen et al. 2004a; Ek et al. 2006).

The E. nigrum L. culture contained the highest concentration of prodelphinidins of all samples, with $2.03 \mathrm{mg} \mathrm{g}^{-1}$ DW. Its procyanidin content was higher than that $\left(3.04 \mathrm{mg} \mathrm{g}^{-1} \mathrm{DW}\right)$, but still distinctly less than the procyanidin content in V. myrtillus. Similar to V. myrtillus, 
Table 4 Compound identification for the Vaccinium myrtillus culture sample Vm2

\begin{tabular}{|c|c|c|c|c|c|c|c|}
\hline Peak & $\begin{array}{l}\text { Tentative compound } \\
\text { identification }\end{array}$ & $\begin{array}{l}\text { Molecular } \\
\text { formula }\end{array}$ & $\operatorname{MS}^{1}(m / z)$ & $\begin{array}{l}\mathrm{MS}^{2}, \text { characteristic } \\
\text { fragments }(\mathrm{m} / \mathrm{z})^{\mathrm{a}}\end{array}$ & $\begin{array}{l}\text { Exact mass, } \\
\text { observed } \\
\left(\mathrm{g} \mathrm{mol}^{-1}\right)\end{array}$ & $\begin{array}{l}\text { Exact mass, } \\
\text { calculated } \\
\left(\mathrm{g} \mathrm{mol}^{-1}\right)\end{array}$ & $\begin{array}{l}\text { Error } \\
(\mathrm{ppm})\end{array}$ \\
\hline 1 & $\begin{array}{l}\text { Coumaroyl hexose } \\
\text { derivative }\end{array}$ & $\mathrm{C}_{15} \mathrm{H}_{18} \mathrm{O}_{8}$ & $\begin{array}{l}651.1934 \\
371.0981 \\
325.0929\end{array}$ & $\begin{array}{l}\text { (371) } 197.0446,167.0337,163.0387 \\
\quad 119.0481 \\
\text { (325) } 163.0386,119.0485\end{array}$ & & & \\
\hline 2 & Catechin & $\mathrm{C}_{15} \mathrm{H}_{14} \mathrm{O}_{6}$ & $\begin{array}{c}869.2294 \\
{[3 \mathrm{M}-\mathrm{H}]^{-}} \\
579.1511 \\
{[2 \mathrm{M}-\mathrm{H}]^{-}} \\
289.0717 \\
{[\mathrm{M}-\mathrm{H}]^{-}}\end{array}$ & (289) $245.0813,125.0227$ & 290.0784 & 290.0790 & -2.0 \\
\hline 3 & $\begin{array}{l}\text { Procyanidin tetramer (1 } \\
\text { A-type bond) }\end{array}$ & $\mathrm{C}_{60} \mathrm{H}_{48} \mathrm{O}_{24}$ & $\begin{array}{c}1151.2457 \\
{[\mathrm{M}-\mathrm{H}]^{-}} \\
575.1200 \\
{[\mathrm{M}-2 \mathrm{H}]^{2-}}\end{array}$ & $\begin{array}{l}\text { (1151) 407.0766, 289.0714, 285.0403, } \\
245.0815,125.0227\end{array}$ & 1152.2524 & 1152.2536 & -1.1 \\
\hline 4 & Coumaroyl hexose & $\mathrm{C}_{15} \mathrm{H}_{18} \mathrm{O}_{8}$ & $\begin{array}{l}651.1935 \\
{[2 \mathrm{M}-\mathrm{H}]^{-}} \\
325.0928 \\
{[\mathrm{M}-\mathrm{H}]^{-}}\end{array}$ & (325) $163.0386,119.0485$ & 326.0995 & 326.1002 & -2.1 \\
\hline 5 & Procyanidin dimer & $\mathrm{C}_{30} \mathrm{H}_{26} \mathrm{O}_{12}$ & $\begin{array}{c}1155.2762 \\
{[2 \mathrm{M}-\mathrm{H}]^{-}} \\
577.1353 \\
{[\mathrm{M}-\mathrm{H}]^{-}}\end{array}$ & $\begin{array}{l}(577) 407.0771,289.0717,245.0813 \\
125.0228\end{array}$ & 578.1420 & 578.1424 & -0.7 \\
\hline 6 & Epicatechin & $\mathrm{C}_{15} \mathrm{H}_{14} \mathrm{O}_{6}$ & $\begin{array}{c}869.2292 \\
{[3 \mathrm{M}-\mathrm{H}]^{-}} \\
579.1509 \\
{[2 \mathrm{M}-\mathrm{H}]^{-}} \\
289.0717 \\
{[\mathrm{M}-\mathrm{H}]^{-}}\end{array}$ & (289) $245.0816,125.0228$ & 290.0784 & 290.0790 & -2.0 \\
\hline 7 & $\begin{array}{l}\text { Procyanidin pentamer (1 } \\
\text { A-type bond) }\end{array}$ & $\mathrm{C}_{75} \mathrm{H}_{60} \mathrm{O}_{30}$ & $\begin{array}{c}1439.3096 \\
{[\mathrm{M}-\mathrm{H}]^{-}} \\
719.1517 \\
{[\mathrm{M}-2 \mathrm{H}]^{2-}}\end{array}$ & $\begin{array}{c}\text { (719) } 407.0764,289.0715,287.0560 \\
285.0403,245.0454,125.0228\end{array}$ & 1440.3163 & 1440.3169 & -0.4 \\
\hline 8 & $\begin{array}{l}\text { Procyanidin trimer ( } 1 \\
\text { A-type bond) }\end{array}$ & $\mathrm{C}_{45} \mathrm{H}_{36} \mathrm{O}_{18}$ & $\begin{array}{c}1727.3720 \\
{[2 \mathrm{M}-\mathrm{H}]^{-}} \\
863.1836 \\
{[\mathrm{M}-\mathrm{H}]^{-}}\end{array}$ & $\begin{array}{c}\text { (863) } 407.0772,289.0718,287.0562 \\
285.0406,245.0452,125.0228\end{array}$ & 864.1903 & 864.1902 & 0.2 \\
\hline 9 & $\begin{array}{l}\text { Procyanidin trimer (1 } \\
\text { A-type bond) }\end{array}$ & $\mathrm{C}_{45} \mathrm{H}_{36} \mathrm{O}_{18}$ & $\begin{array}{c}1727.3699 \\
{[2 \mathrm{M}-\mathrm{H}]^{-}} \\
863.1828 \\
{[\mathrm{M}-\mathrm{H}]^{-}}\end{array}$ & $\begin{array}{l}\text { (863) } 407.0769,289.0717,285.0405 \\
245.0815,125.0228\end{array}$ & 864.1895 & 864.1902 & -0.8 \\
\hline 10 & Procyanidin tetramer & $\mathrm{C}_{60} \mathrm{H}_{50} \mathrm{O}_{24}$ & $\begin{array}{l}1153.2596 \\
{[\mathrm{M}-\mathrm{H}]^{-}} \\
576.1261 \\
{[\mathrm{M}-2 \mathrm{H}]^{2-}}\end{array}$ & $\begin{array}{c}\text { (576) } 407.0766,289.0718,287.0563 \\
285.0406,245.0817,125.0228\end{array}$ & 1154.2663 & 1154.2692 & -2.5 \\
\hline 11 & Procyanidin pentamer & $\mathrm{C}_{75} \mathrm{H}_{62} \mathrm{O}_{30}$ & $\begin{array}{c}1441.3235 \\
{[\mathrm{M}-\mathrm{H}]^{-}} \\
720.1591 \\
{[\mathrm{M}-2 \mathrm{H}]^{2-}}\end{array}$ & $\begin{array}{c}\text { (720) } 407.0769,289.0716,287.0560 \\
285.0408,245.0817,125.0228\end{array}$ & 1442.3302 & 1442.3326 & -1.7 \\
\hline 12 & Quercetin hexoside & $\mathrm{C}_{21} \mathrm{H}_{20} \mathrm{O}_{12}$ & $\begin{array}{l}927.1843 \\
{[2 \mathrm{M}-\mathrm{H}]^{-}} \\
463.0884 \\
{[\mathrm{M}-\mathrm{H}]^{-}}\end{array}$ & (463) 300.0272 & 464.0951 & 464.0955 & -0.9 \\
\hline
\end{tabular}


Table 4 continued

\begin{tabular}{|c|c|c|c|c|c|c|c|}
\hline Peak & $\begin{array}{l}\text { Tentative compound } \\
\text { identification }\end{array}$ & $\begin{array}{l}\text { Molecular } \\
\text { formula }\end{array}$ & $\operatorname{MS}^{1}(m / z)$ & $\begin{array}{l}\mathrm{MS}^{2} \text {, characteristic } \\
\text { fragments }(m / z)^{\mathrm{a}}\end{array}$ & $\begin{array}{l}\text { Exact mass, } \\
\text { observed } \\
\left(\mathrm{g} \mathrm{mol}^{-1}\right)\end{array}$ & $\begin{array}{l}\text { Exact mass, } \\
\text { calculated } \\
\left(\mathrm{g} \mathrm{mol}^{-1}\right)\end{array}$ & $\begin{array}{l}\text { Error } \\
(\mathrm{ppm})\end{array}$ \\
\hline 13 & Procyanidin dimer & $\mathrm{C}_{30} \mathrm{H}_{26} \mathrm{O}_{12}$ & $\begin{array}{l}577.1351 \\
{[\mathrm{M}-\mathrm{H}]^{-}}\end{array}$ & $\begin{array}{l}(577) 407.0772,289.0717,245.0816 \\
125.0228\end{array}$ & 578.1418 & 578.1424 & -1.0 \\
\hline
\end{tabular}

Peak numbers correspond to those presented in Fig. 3

a The ions marked in parentheses were used for $\mathrm{MS}^{2}$ fragmentation experiments

the mean degree of polymerization of proanthocyanidins was calculated, and determined to be 2 , showing clearly smaller oligomers compared to $V$. myrtillus samples on average. Anthocyanins with four different aglycones (cyanidin, delphinidin, peonidin, and petunidin) were detected as well. The UV chromatogram $(\lambda=280 \mathrm{~nm})$ of the E. nigrum culture En is presented in Fig. 4 alongside with a more detailed characterization of the compounds in Table 5. Fragmentation patterns of the E. nigrum sample proanthocyanidins are very similar to the ones observed and described for V. myrtillus, and some ions are seen with $16 \mathrm{Da}$ larger $\mathrm{m} / \mathrm{z}$ values due to the additional hydroxylation of the B-ring in prodelphinidins compared to procyanidins. The coumaric acid derivatives and the quercetin hexose were similar as in V. myrtillus, and the caffeoyl hexoses (Roche et al. 2005) and naringenin hexoside (SánchezRabaneda et al. 2004) were identified using the $\mathrm{MS}^{2}$ fragmentation data. Peak 14 remained unidentified.

The lipophilic phenolic extracts of E. nigrum leaves have been detected to contain chalcones, dihydrochalcones, and dihydrophenanthrene derivatives (Wollenweber et al. 1992), with the hydrophilic phenolic compounds of berries including hydroxycinnamic acids, flavonoids, proanthocyanidins, and high amounts of a wide range of anthocyanins (Määttä-Riihinen et al. 2004a).

The only suspension cultures that could produce proanthocyanidins in amounts comparable to that detected in natural plants were all from the family Ericaceae. In

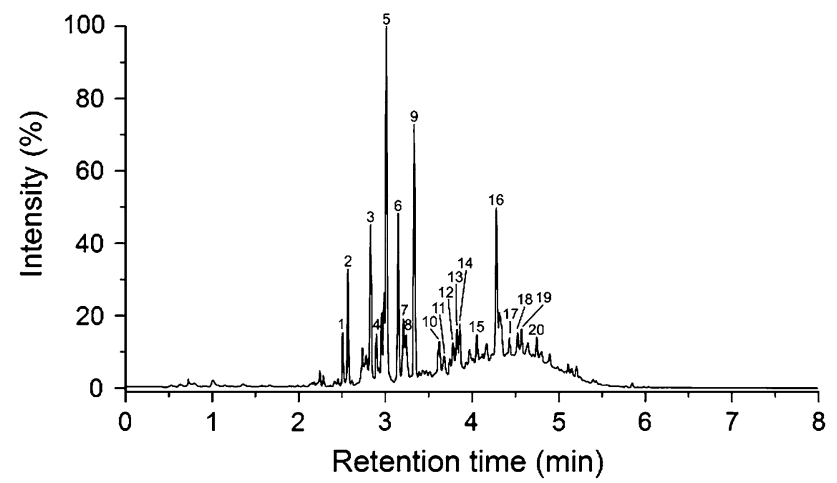

Fig. 4 UHPLC-DAD chromatogram $(\lambda=280 \mathrm{~nm})$ of the E. nigrum suspension culture sample En. For peak identification, see Table 5 addition, all Ericaceae cultures were able to produce at least some amounts of flavonoids similar to their natural counterparts, as evidenced by the presence of kaempferol and quercetin derivatives.

As for the ratio of procyanidins to prodelphinidins, the detected 40:60 ratio of procyanidins to prodelphinidins in the E. nigrum culture is close to the ratio reported in E. nigrum berries (Määttä-Riihinen et al. 2004a). Furthermore, it is clearly different from the ratios in genus Vaccinium cultures, the proanthocyanidins of which consist almost exclusively of procyanidins.

\section{Families Caprifoliaceae and Poaceae}

The L. caerulea L. var. kamtschatica (family Caprifoliaceae) culture was exceptional in that it contained by far the largest concentration of quinic acid derivatives in all of the samples, with only one other sample containing any at all. Quinic acid derivatives also contributed to the majority of its polyphenol profile, with trace amounts of gallic acid derivatives and procyanidins detected.

The taxonomy of some Lonicera species and the varieties of $L$. caerulea is not completely settled, and therefore, also the literature on $L$. caerulea var. kamtschatica is at times ambiguous. The berries contain high quantities of anthocyanins, along with other flavonoids, proanthocyanidins, and phenolic acids (Terahara et al. 1993; Chaovanalikit et al. 2004; Jurikova et al. 2011), while the leaves contain flavonoids and phenolic acids (Oszmianski et al. 2011).

Both the two included cereal cultures from family Poaceae, A. sativa $\mathrm{L}$. and $H$. vulgare $\mathrm{L}$. were low in the analyzed polyphenols, with trace amounts of gallic acid derivatives and procyanidins in both and trace amounts of quinic acid derivatives in one of the $H$. vulgare cultures. The phenolic content of $A$. sativa has been reported to consist mostly of other types of phenolics, mainly avenanthramides (Collins 1989), which are phenolic alkaloids, and simple phenolic acids (Durkee and Thivierge 1977). H. vulgare has also been studied for its phenolic content, and proanthocyanidins and flavonoids contribute to the majority of the phenolic compounds not bound to the cell wall (McMurrough et al. 1996; Ferreres et al. 2009). 
Table 5 Compound identification for the E. nigrum culture sample En

\begin{tabular}{|c|c|c|c|c|c|c|c|}
\hline Peak & $\begin{array}{l}\text { Tentative compound } \\
\text { identification }\end{array}$ & $\begin{array}{l}\text { Molecular } \\
\text { formula }\end{array}$ & $\operatorname{MS}^{1}(m / z)$ & $\begin{array}{l}\mathrm{MS}^{2}, \text { characteristic } \\
\text { fragments }(m / z)^{\mathrm{a}}\end{array}$ & $\begin{array}{l}\text { Exact mass, } \\
\text { observed } \\
\left(\mathrm{g} \mathrm{mol}^{-1}\right)\end{array}$ & $\begin{array}{l}\text { Exact mass, } \\
\text { calculated } \\
\left(\mathrm{g} \mathrm{mol}^{-1}\right)\end{array}$ & $\begin{array}{l}\text { Error } \\
(\mathrm{ppm})\end{array}$ \\
\hline 1 & Caffeoyl hexose & $\mathrm{C}_{15} \mathrm{H}_{18} \mathrm{O}_{9}$ & $\begin{array}{c}683.1831 \\
{[2 \mathrm{M}-\mathrm{H}]^{-}} \\
341.0874 \\
{[\mathrm{M}-\mathrm{H}]^{-}}\end{array}$ & (341) $179.0337,135.0435$ & 342.0941 & 342.0951 & -2.9 \\
\hline 2 & $\begin{array}{l}\text { Coumaroyl hexose } \\
\text { derivative }\end{array}$ & & $\begin{array}{l}651.1934 \\
371.0979 \\
325.0929\end{array}$ & $\begin{array}{l}\text { (371) } 163.0386,119.0485 \\
(325) 163.0386,119.0485\end{array}$ & & & \\
\hline 3 & Caffeoyl hexose & $\mathrm{C}_{15} \mathrm{H}_{18} \mathrm{O}_{9}$ & $\begin{array}{c}683.1831 \\
{[2 \mathrm{M}-\mathrm{H}]^{-}} \\
341.0870 \\
{[\mathrm{M}-\mathrm{H}]^{-}}\end{array}$ & (683) $179.0337,135.0435$ & 342.0936 & 342.0951 & -4.4 \\
\hline 4 & Catechin & $\mathrm{C}_{15} \mathrm{H}_{14} \mathrm{O}_{6}$ & $\begin{array}{c}869.2296 \\
{[3 \mathrm{M}-\mathrm{H}]^{-}} \\
579.1511 \\
{[2 \mathrm{M}-\mathrm{H}]^{-}} \\
289.0718 \\
{[\mathrm{M}-\mathrm{H}]^{-}}\end{array}$ & (289) $245.0814,125.0227$ & 290.0785 & 290.0790 & -1.7 \\
\hline 5 & Coumaroyl hexose & $\mathrm{C}_{15} \mathrm{H}_{18} \mathrm{O}_{8}$ & $\begin{array}{c}651.1934 \\
{[2 \mathrm{M}-\mathrm{H}]^{-}} \\
325.0919 \\
{[\mathrm{M}-\mathrm{H}]^{-}}\end{array}$ & (325) $163.0386,119.0485$ & 326.0986 & 326.1002 & -4.9 \\
\hline 6 & Coumaroyl hexose & $\mathrm{C}_{15} \mathrm{H}_{18} \mathrm{O}_{8}$ & $\begin{array}{c}651.1934 \\
{[2 \mathrm{M}-\mathrm{H}]^{-}} \\
325.0917 \\
{[\mathrm{M}-\mathrm{H}]^{-}}\end{array}$ & $\begin{array}{l}\text { (325) } 163.0386,145.0279 \\
119.0484\end{array}$ & 326.0984 & 326.1002 & -5.5 \\
\hline 7 & Caffeoyl hexose & $\mathrm{C}_{15} \mathrm{H}_{18} \mathrm{O}_{9}$ & $\begin{array}{c}683.1824 \\
{[2 \mathrm{M}-\mathrm{H}]^{-}} \\
341.0870 \\
{[\mathrm{M}-\mathrm{H}]^{-}}\end{array}$ & (683) 179.0337, 135.0435 & 342.0936 & 342.0951 & -4.4 \\
\hline 8 & Procyanidin dimer & $\mathrm{C}_{30} \mathrm{H}_{26} \mathrm{O}_{12}$ & $\begin{array}{c}1155.2764 \\
{[2 \mathrm{M}-\mathrm{H}]^{-}} \\
577.1353 \\
{[\mathrm{M}-\mathrm{H}]^{-}}\end{array}$ & $\begin{array}{l}\text { (577) } 407.0770,289.0716 \\
245.0818,125.0228\end{array}$ & 578.1420 & 578.1424 & -0.7 \\
\hline 9 & Epicatechin & $\mathrm{C}_{15} \mathrm{H}_{14} \mathrm{O}_{6}$ & $\begin{array}{c}869.2303 \\
{[3 \mathrm{M}-\mathrm{H}]^{-}} \\
579.1510 \\
{[2 \mathrm{M}-\mathrm{H}]^{-}} \\
289.0718 \\
{[\mathrm{M}-\mathrm{H}]^{-}}\end{array}$ & (289) $245.0812,125.0227$ & 290.0785 & 290.0790 & -1.7 \\
\hline 10 & $\begin{array}{l}\text { Procyanidin trimer ( } 1 \\
\text { A-type bond) }\end{array}$ & $\mathrm{C}_{45} \mathrm{H}_{36} \mathrm{O}_{18}$ & $\begin{array}{c}863.1832 \\
{[\mathrm{M}-\mathrm{H}]^{-}}\end{array}$ & $\begin{array}{l}\text { (863) 407.0767, 289.0715, } \\
287.0559,285.0403,245.0450 \\
125.0228\end{array}$ & 864.1899 & 864.1902 & -0.4 \\
\hline 11 & $\begin{array}{l}\text { Procyanidin- } \\
\text { prodelphinidin trimer } \\
\text { (1 A-type bond) }\end{array}$ & $\mathrm{C}_{45} \mathrm{H}_{36} \mathrm{O}_{19}$ & $\begin{array}{r}879.1785 \\
{[\mathrm{M}-\mathrm{H}]^{-}}\end{array}$ & $\begin{array}{l}\text { (879) } 407.0770,301.0352, \\
289.0717,285.0404,125.0228\end{array}$ & 880.1852 & 880.1851 & 0.2 \\
\hline 12 & $\begin{array}{l}\text { Procyanidin- } \\
\text { prodelphinidin dimer } \\
\text { (A-type bond) }\end{array}$ & $\mathrm{C}_{30} \mathrm{H}_{24} \mathrm{O}_{13}$ & $\begin{array}{c}1183.2353 \\
{[2 \mathrm{M}-\mathrm{H}]^{-}} \\
591.1150 \\
{[\mathrm{M}-\mathrm{H}]^{-}}\end{array}$ & $\begin{array}{l}(591) 407.0768,305.0662 \\
301.0352,289.0713,285.0404 \\
125.0227\end{array}$ & 592.1217 & 592.1217 & 0.1 \\
\hline 13 & $\begin{array}{l}\text { Procyanidin trimer ( } 1 \\
\text { A-type bond) }\end{array}$ & $\mathrm{C}_{45} \mathrm{H}_{36} \mathrm{O}_{18}$ & $\begin{array}{l}863.1829 \\
{[\mathrm{M}-\mathrm{H}]^{-}}\end{array}$ & $\begin{array}{c}\text { (863) } 407.0769,289.0717 \\
285.0406,125.0228\end{array}$ & 864.1896 & 864.1902 & -0.7 \\
\hline
\end{tabular}


Table 5 continued

\begin{tabular}{|c|c|c|c|c|c|c|c|}
\hline Peak & $\begin{array}{l}\text { Tentative compound } \\
\text { identification }\end{array}$ & $\begin{array}{l}\text { Molecular } \\
\text { formula }\end{array}$ & $\operatorname{MS}^{1}(m / z)$ & $\begin{array}{l}\mathrm{MS}^{2}, \text { characteristic } \\
\text { fragments }(\mathrm{m} / \mathrm{z})^{\mathrm{a}}\end{array}$ & $\begin{array}{l}\text { Exact mass, } \\
\text { observed } \\
\left(\mathrm{g} \mathrm{mol}^{-1}\right)\end{array}$ & $\begin{array}{l}\text { Exact mass, } \\
\text { calculated } \\
\left(\mathrm{g} \mathrm{mol}^{-1}\right)\end{array}$ & $\begin{array}{l}\text { Error } \\
(\mathrm{ppm})\end{array}$ \\
\hline 14 & Unknown & & $\begin{array}{l}931.2152 \\
465.1035\end{array}$ & $\begin{array}{c}\text { (465) } 437.1089,275.0561 \\
259.0612,125.0228\end{array}$ & & & \\
\hline 15 & Quercetin hexoside & $\mathrm{C}_{21} \mathrm{H}_{20} \mathrm{O}_{12}$ & $\begin{array}{c}927.1840 \\
{[2 \mathrm{M}-\mathrm{H}]^{-}} \\
463.0884 \\
{[\mathrm{M}-\mathrm{H}]^{-}}\end{array}$ & (463) 300.0273 & 464.0951 & 464.0955 & -0.9 \\
\hline 16 & $\begin{array}{l}\text { Procyanidin tetramer ( } 1 \\
\text { A-type bond) }\end{array}$ & $\mathrm{C}_{60} \mathrm{H}_{48} \mathrm{O}_{24}$ & $\begin{array}{c}1151.2463 \\
{[\mathrm{M}-\mathrm{H}]^{-}} \\
575.1198 \\
{[\mathrm{M}-2 \mathrm{H}]^{2-}}\end{array}$ & $\begin{array}{l}\text { (575) } 407.0768,289.0716 \\
285.0404,125.0228\end{array}$ & 1152.2530 & 1152.2536 & -0.5 \\
\hline 17 & $\begin{array}{l}\text { Procyanidin trimer ( } 1 \\
\text { A-type bond) }\end{array}$ & $\mathrm{C}_{45} \mathrm{H}_{36} \mathrm{O}_{18}$ & $\begin{array}{c}863.1835 \\
{[\mathrm{M}-\mathrm{H}]^{-}}\end{array}$ & $\begin{array}{c}\text { (863) } 407.0768,289.0715 \\
285.0402,125.0227\end{array}$ & 864.1902 & 864.1902 & 0.1 \\
\hline 18 & $\begin{array}{l}\text { Procyanidin dimer (A- } \\
\text { type bond) }\end{array}$ & $\mathrm{C}_{30} \mathrm{H}_{24} \mathrm{O}_{12}$ & $\begin{array}{c}1151.2451 \\
{[2 \mathrm{M}-\mathrm{H}]^{-}} \\
575.1201 \\
{[\mathrm{M}-\mathrm{H}]^{-}}\end{array}$ & $\begin{array}{c}(575) 407.0769,289.0714 \\
285.0402,125.0227\end{array}$ & 576.1268 & 576.1268 & 0.1 \\
\hline 19 & $\begin{array}{l}\text { Procyanidin trimer ( } 2 \\
\text { A-type bonds) }\end{array}$ & $\mathrm{C}_{45} \mathrm{H}_{34} \mathrm{O}_{18}$ & $\begin{array}{c}861.1673 \\
{[\mathrm{M}-\mathrm{H}]^{-}}\end{array}$ & $\begin{array}{c}\text { (861) 407.0769, 289.0715, } \\
285.0402,125.0228\end{array}$ & 862.1742 & 862.1745 & -0.4 \\
\hline 20 & Naringenin hexoside & $\mathrm{C}_{21} \mathrm{H}_{22} \mathrm{O}_{10}$ & $\begin{array}{r}433.1141 \\
{[\mathrm{M}-\mathrm{H}]^{-}}\end{array}$ & (433) 271.0610, 151.0022 & 434.1208 & 434.1213 & -1.1 \\
\hline
\end{tabular}

Peak numbers correspond to those presented in Fig. 4

a The ions marked in parentheses were used for $\mathrm{MS}^{2}$ fragmentation experiments

\section{Culture conditions}

As described, the suspension cultures used in this study were mostly grown under similar conditions, with the exception of the Poaceae samples As and Hv1. The growth media, however, differed between the samples (Table 1), with a total of six different media being used, which was due to the fact that the conditions were not optimized for polyphenol accumulation, but for general growth. The cultivation of the plant cells also differed for some samples as has been described earlier; most were cultivated in Erlenmeyer flasks, but different cultivation methods were used for Rc1, Rc2, Sa1, and Sa2. The accumulation of phenolic compounds in cell cultures is highly dependent on the concentrations of the plant growth regulators, auxins, and cytokinins, and their ratio (Dias et al. 2016). As for polyphenolic compounds, other published examples of the effects of these types of adjustments to the conditions include the inhibition of the production of ellagitannins by $\mathrm{NH}_{4}{ }^{+}$in the medium (Ishimaru and Shimomura 1991) and the accumulation of anthocyanins and proanthocyanidins when using appropriate concentrations of sucrose (Decendit and Mérillon 1996). It must be noted that all these choices along with, for instance, the age of the culture and sub-culturing can cause the polyphenol profile to be vastly different even within a species. All of these naturally also influence how closely the cell cultures resemble their wild counterparts. Depending on these factors, reports on the polyphenolic profile of cell cultures may closely match that of the wild plants' certain plant parts (e.g., our samples Vm1 and Vm2, Decendit and Mérillon 1996), be somewhat similar (e.g., our samples Rs1 and Rs2, López Arnaldos et al. 2001), or even remarkably different (e.g., our samples Sa1 and Sa2, Nohynek et al. 2014), making comparisons between different studies sometimes troublesome. Therefore, our results are not fully comparable in all cases to each other or to other culture studies involving the same species.

\section{Conclusions}

Many of the studied cell suspension cultures proved to be relatively low in polyphenol content when compared to plants. The most distinctive exceptions to this were $S$. $a u$ cuparia, V. myrtillus, and E. nigrum, which, when combined, produced a comprehensive set of different polyphenolic compounds, including oligomeric tannins.

The cultures of the two families which were represented by three or more species showed capability to produce 
polyphenolic content representative for their natural counterparts. Rosaceae cultures produced the highest concentrations of hydrolysable tannins but not much proanthocyanidins, while Ericaceae cultures produced high concentrations of proanthocyanidins and in the case of $V$. myrtillus levels comparable to even its berries and leaves. Anthocyanins were detected in several of the species they naturally occur in, but the concentrations were lower than what has been detected in the berries.

Several cell suspension cultures originating from Rosaceae plants could be potentially used for further studies involving hydrolysable tannins, as some of them exhibited ellagitannin accumulation, and most of them produced galloyl glucoses.

Author contribution statement JS did the mass spectrometric analyses for all compound groups except for anthocyanins, analyzed the data, and wrote the bulk of the article. LN, HR, and RP-P designed and cultivated the cell cultures, and LN wrote the corresponding text. TS-L did the anthocyanin analyses and wrote the basis for the corresponding text. HR, J-PS, LN, and RP-P designed the research. All authors read, commented on, and approved the manuscript.

Acknowledgements Airi Hyrkäs, Siv Matomaa, and Tuuli Teikari are acknowledged for technical assistance with cell cultures and sample preparation. Anne Koivuniemi is acknowledged for help in the development of the calibration curves, and Maarit Karonen and Petri Tähtinen for their comments on earlier versions of the manuscript. Academy of Finland ("Novel approach to modulate and characterize ellagitannin biodiversity in Rubus cell and organ cultures", project 276527 to RP-P and "Evolution and global distribution of plant polyphenol-based pro-oxidant defenses", project 258992 to J-PS) is acknowledged for financial support.

\section{Compliance with ethical standards}

Conflict of interest The authors declare that they have no conflict of interest.

Open Access This article is distributed under the terms of the Creative Commons Attribution 4.0 International License (http://crea tivecommons.org/licenses/by/4.0/), which permits unrestricted use, distribution, and reproduction in any medium, provided you give appropriate credit to the original author(s) and the source, provide a link to the Creative Commons license, and indicate if changes were made.

\section{References}

Aaby K, Ekeberg D, Skrede G (2007) Characterization of phenolic compounds in strawberry (Fragaria $\times$ ananassa) fruits by different HPLC detectors and contribution of individual compounds to total antioxidant capacity. J Agric Food Chem 55:4395-4406. doi:10.1021/jf0702592

Andersen ØM (1985) Chromatographic separation of anthocyanins in cowberry (lingonberry) Vaccinium vites-idaea L. J Food Sci 50:1230-1232. doi:10.1111/j.1365-2621.1985.tb10449.x
Barbulova A, Apone F, Colucci G (2014) Plant cell cultures as source of cosmetic active ingredients. Cosmetics 1:94-104. doi:10. 3390/cosmetics1020094

Buendía B, Gil MI, Tudela JA, Gady AL, Medina JJ, Soria C, López JM, Tomás-Barberán FA (2010) HPLC-MS analysis of proanthocyanidin oligomers and other phenolics in 15 strawberry cultivars. J Agric Food Chem 58:3916-3926. doi:10.1021/ jf9030597

Chalker-Scott L (1999) Environmental significance of anthocyanins in plant stress responses. Photochem Photobiol 70:1-9. doi:10. 1111/j.1751-1097.1999.tb01944.x

Chaovanalikit A, Thompson MM, Wrolstad RE (2004) Characterization and quantification of anthocyanins and polyphenolics in blue honeysuckle (Lonicera caerulea L.). J Agric Food Chem 52:848-852. doi:10.1021/jf030509o

Collins FW (1989) Oat phenolics: avenanthramides, novel substituted $N$-cinnamoylanthranilate alkaloids from oat groats and hulls. J Agric Food Chem 37:60-66. doi:10.1021/jf00085a015

Constabel F (1968) Gerbstoffproduktion der calluskulturen von Juniperus communis L. Planta 79:58-64. doi:10.1007/ BF00388822

Davies ME (1972) Polyphenol synthesis in cell suspension cultures of Paul's Scarlet rose. Planta 104:50-65. doi:10.1007/BF00387683

Decendit A, Mérillon J (1996) Condensed tannin and anthocyanin production in Vitis vinifera cell suspension cultures. Plant Cell Rep 15:762-765. doi:10.1007/s002990050116

Dias MI, Sousa MJ, Alves RC, Ferreira ICFR (2016) Exploring plant tissue culture to improve the production of phenolic compounds: a review. Ind Crop Prod 82:9-22. doi:10.1016/j.indcrop.2015.12. 016

Durkee AB, Thivierge PA (1977) Ferulic acid and other phenolics in oat seeds (Avena sativa L. var Hinoat). J Food Sci 42:551-552. doi:10.1111/j.1365-2621.1977.tb01547.x

Ek S, Kartimo H, Mattila S, Tolonen A (2006) Characterization of phenolic compounds from lingonberry (Vaccinium vitis-idaea). J Agric Food Chem 54:9834-9842. doi:10.1021/jf0623687

Engström MT, Pälijärvi M, Fryganas C, Grabber JH, Mueller-Harvey I, Salminen J-P (2014) Rapid qualitative and quantitative analyses of proanthocyanidin oligomers and polymers by UPLC-MS/MS. J Agric Food Chem 62:3390-3399. doi:10. 1021/jf500745y

Engström MT, Pälijärvi M, Salminen J-P (2015) Rapid fingerprint analysis of plant extracts for ellagitannins, gallic acid, and quinic acid derivatives and quercetin-, kaempferol- and myricetin-based flavonol glycosides by UPLC-QqQ-MS/MS. J Agric Food Chem 63:4068-4079. doi:10.1021/acs.jafc.5b00595

Espín JC, García-Conesa MT, Tomás-Barberán FA (2007) Nutraceuticals: facts and fiction. Phytochemistry 68:2986-3008. doi:10. 1016/j.phytochem.2007.09.014

Ferreres F, Kršková Z, Gonçalves RF, Valentão P, Pereira JA, Dušek J, Martin J, Andrade PB (2009) Free water-soluble phenolics profiling in barley (Hordeum vulgare L.). J Agric Food Chem 57:2405-2409. doi:10.1021/jf8037727

Friedrich W, Eberhardt A, Galensa R (2000) Investigation of proanthocyanidins by HPLC with electrosprayionization mass spectrometry. Eur Food Res Technol 211:56-64. doi:10.1007/ s002170050589

Gil MI, Holcroft DM, Kader AA (1997) Changes in strawberry anthocyanins and other polyphenols in response to carbon dioxide treatments. J Agric Food Chem 45:1662-1667. doi:10. 1021/jf960675e

Gu L, Kelm MA, Hammerstone JF, Zhang Z, Beecher G, Holden J, Haytowitz D, Prior RL (2003) Liquid chromatographic/electrospray ionization mass spectrometric studies of proanthocyanidins in foods. J Mass Spectrom 38:1272-1280. doi:10.1002/jms.541 
Haddock EA, Gupta RK, Al-Shafi SMK, Layden K, Haslam E, Magnolato D (1982) The metabolism of gallic acid and hexahydroxydiphenic acid in plants: biogenetic and molecular taxonomic considerations. Phytochemistry 21:1049-1062. doi:10.1016/S0031-9422(00)82415-2

Hagerman AE, Riedl KM, Jones GA, Sovik KN, Ritchard NT, Hartzfeld PW, Riechel TL (1998) High molecular weight plant polyphenolics (tannins) as biological antioxidants. J Agric Food Chem 46:1887-1892. doi:10.1021/jf970975b

Häkkinen S, Auriola S (1998) High-performance liquid chromatography with electrospray ionization mass spectrometry and diode array ultraviolet detection in the identification of flavonol aglycones and glycosides in berries. J Chromatogr A 829:91-100. doi:10.1016/S0021-9673(98)00756-0

Häkkinen S, Heinonen M, Kärenlampi S, Mykkänen H, Ruuskanen J, Törrönen R (1999) Screening of selected flavonoids and phenolic acids in 19 berries. Food Res Int 32:345-353. doi:10.1016/ S0963-9969(99)00095-2

Harborne JB, Hall E (1964) Plant polyphenols-XIII. The systematic distribution and origin of anthocyanins containing branched trisaccharides. Phytochemistry 3:453-463. doi:10.1016/S00319422(00)83630-4

Haukioja E (1991) Induction of defenses in trees. Annu Rev Entomol 36:25-42. doi:10.1146/annurev.en.36.010191.000325

Henning W (1981) Flavonolglykoside der erdbeeren (Fragaria $\times$ ananassa Duch.), himbeeren (Rubus idaeus L.) und brombeeren (Rubus fruticosus L.). Z Lebensm Unters For 173:180-187. doi:10.1007/BF01041978

Hokkanen J, Mattila S, Jaakola L, Pirttilä AM, Tolonen A (2009) Identification of phenolic compounds from lingonberry (Vaccinium vitis-idaea L.), bilberry (Vaccinium myrtillus L.) and hybrid bilberry (Vaccinium $\times$ intermedium Ruthe L.) leaves. J Agric Food Chem 57:9437-9447. doi:10.1021/jf9022542

Hvattum E, Ekeberg D (2003) Study of the collision-induced radical cleavage of flavonoid glycosides using negative electrospray ionization tandem quadrupole mass spectrometry. J Mass Spectrom 38:43-49. doi:10.1002/jms.398

Ishimaru K, Shimomura K (1991) Tannin production in hairy root culture of Geranium thunbergii. Phytochemistry 30:825-828. doi:10.1016/0031-9422(91)85260-7

Jaakola L, Määttä-Riihinen K, Kärenlampi S, Hohtola A (2004) Activation of flavonoid biosynthesis by solar radiation in bilberry (Vaccinium myrtillus L.) leaves. Planta 218:721-728. doi:10.1007/s00425-003-1161-x

Jurikova T, Rop O, Mlcek J, Sochor J, Balla S, Szekeres L, Hegedusova A, Hubalek J, Adam V, Kizek R (2011) Phenolic profile of edible honeysuckle berries (genus Lonicera) and their biological effects. Molecules 17:61-79. doi:10.3390/ molecules 17010061

Kähkönen MP, Hopia AI, Heinonen M (2001) Berry phenolics and their antioxidant activity. J Agric Food Chem 49:4076-4082. doi:10.1021/jf010152t

Kårlund A, Salminen J-P, Koskinen P, Ahern JR, Karonen M, Tiilikkala K, Karjalainen RO (2014) Polyphenols in strawberry (Fragaria $\times$ ananassa) leaves induced by plant activators. J Agric Food Chem 62:4592-4600. doi:10.1021/jf405589f

Karonen M, Liimatainen J, Sinkkonen J (2011) Birch inner bark procyanidins can be resolved with enhanced sensitivity by hydrophilic interaction HPLC-MS. J Sep Sci 34:3158-3165. doi: $10.1002 /$ jssc. 201100569

Krajci I, Gross GG (1986) Formation of gallotannins in callus cultures from oak (Quercus robur). Phytochemistry 26:141-143. doi:10. 1016/S0031-9422(00)81498-3

Kylli P, Nohynek L, Puupponen-Pimiä R, Westerlund-Wikström B, McDougall G, Stewart D, Heinonen M (2010) Rowanberry phenolics: compositional analysis and bioactivities. J Agric Food Chem 58:11985-11992. doi:10.1021/jf102739v

Lee J-H, Johnson JV, Talcott ST (2005) Identification of ellagic acid conjugates and other polyphenolics in muscadine grapes by HPLC-ESI-MS. J Agric Food Chem 53:6003-6010. doi:10. 1021/jf050468r

López Arnaldos T, Muñoz R, Angeles Ferrer M, Calderón AA (2001) Changes in phenol content during strawberry (Fragaria $\times$ ananassa, cv. Chandler) callus culture. Physiol Plant 113:315-322. doi:10.1034/j.1399-3054.2001.1130303.x

Ma C, Xiao S, Li Z, Wang W, Du L (2007) Characterization of active phenolic components in the ethanolic extract of Ananas comosus L. leaves using high-performance liquid chromatography with diode array detection and tandem mass spectrometry. J Chromatogr A 1165:39-44. doi:10.1016/j.chroma.2007.07.060

Määttä-Riihinen KR, Kamal-Eldin A, Mattila PH, González-Paramás AM, Törrönen AR (2004a) Distribution and contents of phenolic compounds in eighteen Scandinavian berry species. J Agric Food Chem 52:4477-4486. doi:10.1021/jf049595y

Määttä-Riihinen KR, Kamal-Eldin A, Törrönen AR (2004b) Identification and quantification of phenolic compounds in berries of Fragaria and Rubus species (family Rosaceae). J Agric Food Chem 52:6178-6187. doi:10.1021/jf049450r

Madhan B, Subramanian V, Rao JR, Nair BU, Ramasami T (2005) Stabilization of collagen using plant polyphenol: role of catechin. Int J Biol Macromol 37:47-53. doi:10.1016/j.ijbio mac.2005.08.005

Matkowski A (2008) Plant in vitro culture for the production of antioxidants-a review. Biotechnol Adv 26:548-560. doi:10. 1016/j.biotechadv.2008.07.001

McMurrough I, Madigan D, Smyth MR (1996) Semipreparative chromatographic procedure for the isolation of dimeric and trimeric proanthocyanidins from barley. J Agric Food Chem 44:1731-1735. doi:10.1021/jf960139m

Moilanen J, Koskinen P, Salminen J-P (2015) Distribution and content of ellagitannins in Finnish plant species. Phytochemistry 116:188-197. doi:10.1016/j.phytochem.2015.03.002

Murashige T, Skoog F (1962) A revised medium for rapid growth and bio assays with tobacco tissue cultures. Physiol Plant 15:473-497. doi:10.1111/j.1399-3054.1962.tb08052.x

Nawa Y, Asano S, Motoori S, Ohtani T (1993) Production of anthocyanins, carotenoids, and proanthocyanidins by cultured cells of rabbiteye blueberry (Vaccinium ashei Reade). Biosci Biotechnol Biochem 57:770-774. doi:10.1271/bbb.57.770

Nichols JA, Katiyar SK (2010) Skin photoprotection by natural polyphenols: anti-inflammatory, antioxidant and DNA repair mechanisms. Arch Dermatol Res 302:71-83. doi:10.1007/ s00403-009-1001-3

Nohynek LJ, Alakomi H-L, Kähkönen MP, Heinonen M, Helander IM，Oksman-Caldentey K-M，Puupponen-Pimiä RH (2006) Berry phenolics: antimicrobial properties and mechanisms of action against severe human pathogens. Nutr Cancer 54:18-32. doi:10.1207/s15327914nc5401_4

Nohynek L, Bailey M, Tähtiharju J, Seppänen-Laakso T, Rischer H, Oksman-Caldentey K-M, Puupponen-Pimiä R (2014) Cloudberry (Rubus chamaemorus) cell culture with bioactive substances: establishment and mass propagation for industrial use. Eng Life Sci 14:667-675. doi:10.1002/elsc.201400069

Oberthur EE, Nicholson RL, Butler LG (1983) Presence of polyphenolic materials, including condensed tannins, in sorghum callus. J Agric Food Chem 31:660-662. doi:10.1021/jf00117a047

Okuda T, Yoshida T, Hatano T, Iwasaki M, Kubo M, Orime T, Yoshizaki M, Naruhashi N (1992) Hydrolysable tannins as chemotaxonomic markers in the Rosaceae. Phytochemistry 31:3091-3096. doi:10.1016/0031-9422(92)83451-4 
Okuda T, Yoshida T, Hatano T, Ito H (2009) Ellagitannins renewed the concept of tannins. In: Quideau S (ed) Chemistry and biology of ellagitannins: an underestimated class of bioactive plant polyphenols. World Scientific Publishing Co. Pte. Ltd., Singapore, pp 1-54. doi:10.1142/9789812797414_0001

Olszewska MA, Michel P (2009) Antioxidant activity of inflorescences, leaves and fruits of three Sorbus species in relation to their polyphenolic composition. Nat Prod Res 23:1507-1521. doi:10.1080/14786410802636177

Oszmiański J, Wojdylo A, Gorzelany J, Kapusta I (2011) Identification and characterization of low molecular weight polyphenols in berry leaf extracts by HPLC-DAD and LC-ESI/MS. J Agric Food Chem 59:12830-12835. doi:10.1021/jf203052j

Parvez S, Kang M, Chung H-S, Bae H (2007) Naturally occurring tyrosinase inhibitors: mechanism and applications in skin health, cosmetics and agriculture industries. Phytother Res 21:805-816. doi: $10.1002 /$ ptr. 2184

Pérez-Magariño S, Revilla I, González-SanJosé ML, Beltrán S (1999) Various applications of liquid chromatography-mass spectrometry to the analysis of phenolic compounds. J Chromatogr A 847:75-81. doi:10.1016/S0021-9673(99)00255-1

Primetta AK, Jaakola L, Ayaz FA, Inceer H, Riihinen KR (2013) Anthocyanin fingerprinting for authenticity studies of bilberry (Vaccinium myrtillus L.). Food Control 30:662-667. doi:10. 1016/j.foodcont.2012.09.009

Riihinen K, Jaakola L, Kärenlampi S, Hohtola A (2008) Organspecific distribution of phenolic compounds in bilberry (Vaccinium myrtillus) and 'northblue' blueberry (Vaccinium corymbosum $\times V$. angustifolium). Food Chem 110:156-160. doi:10. 1016/j.foodchem.2008.01.057

Ritala A, Mannonen L, Aspegren K, Salmenkallio-Marttila M, Kurtén U, Hannus R, Mendez Lozano J, Teeri TH, Kauppinen V (1993) Stable transformation of barley tissue culture by particle bombardment. Plant Cell Rep 12:435-440. doi:10.1007/ BF00234708

Ritala A, Suortti T, Kalendar R, Salmenkallio-Marttila M, OksmanCaldentey K-M, Schulman A, Nuutila AM (2007) Geeninsiirtojen hyödyntäminen jalostuksessa. In: Kiviharju E, Ritala A, Schulman A, Pietilä L, Tanhuanpää P (eds) Biotekniikka kauran jalostuksessa. Uudet menetelmät laadun parantamiseksi, Maa-ja elintarviketalous, vol 99. MTT, Jokioinen, pp 34-58

Ritala A, Wahlström EH, Holkeri H, Hafren A, Mäkeläinen K, Baez J, Mäkinen K, Nuutila AM (2008) Production of recombinant industrial protein using barley cell cultures. Protein Expres Purif 59:274-281. doi:10.1016/j.pep.2008.02.013
Roche M, Dufour C, Mora N, Dangles O (2005) Antioxidant activity of olive phenols: mechanistic investigation and characterization of oxidation products by mass spectrometry. Org Biomol Chem 3:423-430. doi:10.1039/b416101g

Ryan JJ, Coffin DE (1971) Flavonol glucuronides from red raspberry, Rubus ideaeus (Rosaceae). Phytochemistry 10:1675-1677. doi:10.1016/0031-9422(71)85048-3

Sánchez-Rabaneda F, Jáuregui O, Lamuela-Raventós RM, Viladomat F, Bastida J, Codina C (2004) Qualitative analysis of phenolic compounds in apple pomace using liquid chromatography coupled to mass spectrometry in tandem mode. Rapid Commun Mass Spectrom 18:553-563. doi:10.1002/rcm.1370

Scalbert A, Monties B, Favre J-M (1988) Polyphenols of Quercus robur: adult tree and in vitro grown calli and shoots. Phytochemistry 27:3483-3488. doi:10.1016/0031-9422(88)80753-2

Serrano J, Puupponen-Pimiä R, Dauer A, Aura A-M, Saura-Calixto F (2009) Tannins: current knowledge of food sources, intake, bioavailability and biological effects. Mol Nutr Food Res 53:S310-S329. doi:10.1002/mnfr.200900039

Skupień K, Oszmiański J (2004) Comparison of six cultivars of strawberries (Fragaria $\times$ ananassa Duch.) grown in northwest Poland. Eur Food Res Technol 219:66-70. doi:10.1007/s00217004-0918-1

Suomalainen H, Keränen AJA (1961) The first anthocyanins appearing during the ripening of blueberries. Nature 191:498-499. doi:10.1038/191498a0

Terahara N, Sakanashi T, Tsukui A (1993) Anthocyanins from the berries of haskaap, Lonicera caerulea L. J Home Econ Japan 44:197-201. doi:10.11428/jhej1987.44.197

Törrönen R, Häkkinen S, Kärenlampi S, Mykkänen H (1997) Flavonoids and phenolic acids in selected berries. Cancer Lett 114:191-192. doi:10.1016/S0304-3835(97)04660-0

Wildanger W, Herrmann K (1973) Die phenolischen inhaltsstoffe des obstes. II. Die flavonole des obstes. Z Lebensm Unters For 151:103-108. doi:10.1007/BF01842919

Wollenweber E, Dörr M, Stelzer R, Arriaga-Giner FJ (1992) Lipophilic phenolics from the leaves of Empetrum nigrumchemical structures and exudate localization. Bot Acta 105:300-305. doi:10.1111/j.1438-8677.1992.tb00302.x

Zillich OV, Schweiggert-Weisz U, Eisner P, Kerscher M (2015) Polyphenols as active ingredients for cosmetic products. Int $\mathbf{J}$ Cosmetic Sci 37:455-464. doi:10.1111/ics.12218 